\title{
Etična socialnodelovna praksa v pandemičnem času
}

\begin{abstract}
Socialno delo, poklic, prežet $z$ etičnimi dilemami, je bilo $v$ času pandemije covid-19 pred velikimi izzivi, sajsejespoprijemaloz novimi načinidela, poglobljenimistiskami, pomanjkanjem materialnih in človeških virov ipd. O tem so poročale tudi udeleženke mednarodne raziskave, ki je predstavljena v članku. Prepoznanih je bilo šest področij, ki so bila za respondentke osrednja v zvezi z etičnimi izzivi v času pandemije. Na podlagi rezultatov te raziskave so predstavljena priporočila za etično ravnanje socialnih delavk pa tudi za kolektivne usmeritve poklica, podporo organizacij, kjer socialne delavke delujejo, in javno prepoznanje stroke socialnega dela. Predstavljena je tudi preprosta hevristika za ravnanje z etičnimi dilemami, ki je lahko opomnik za premislek o procesih iskanja etičnih odločitev. Avtorica prispevek sklene s pozivom k nujnosti krepitve etične usmerjenosti stroke na individualni, organizacijski in kolektivni ravni.
\end{abstract}

Ključne besede: etika, etične dileme, covid-19, vrednote, etično odločanje, priporočila.

Dr. Ana M. Sobočan je docentka in raziskovalka na Fakulteti za socialno delo. Njeni osrednji raziskovalni temi sta etika v socialnem delu in etika v raziskovanju. Kontakt:ana.sobocan@fsd.uni-lj.si.

\section{Ethical social work practice in times of the pandemic}

Social work, a profession steeped in ethical dilemmas, faced great challenges during the Covid-19 pandemic as it was confronted with new forms of work, intensifying hardships, lack of material and human resources, etc. This was also reported by the participants of the international research, which is briefly presented in this article. In the research, six fields were identified that were central to the research participants in relation to ethical challenges during the pandemic. Based on the findings of this research, ethical guidelines are presented - for individual practitioners, as well as for collective professional orientations, support for the organizations in which social workers practice, and for recognition of the profession of social work. The paper also includes a brief presentation of a simple heuristic for dealing with ethical dilemmas that can serve as a reminder to think about the processes of seeking ethical solutions. The author concludes with a call for strengthening the ethical character of the profession at individual, organizational and collective levels.

Key words: ethics, ethical dilemmas, covid-19, values, ethical decision-making, guidelines.

Ana M. Sobočan, PhD, is assistant professor and researcher at the Faculty of Social Work, University or Ljubljana. Her main foci in research are ethics in social work and research ethics. Contact: ana. sobocan@fsd.uni-lj.si.

\section{Uvod: pandemija covida-19 in socialno delo}

Socialno delo je poklic, ki temelji tudi na vrednotah, in socialne delavke so zavezane k delovanju, ki udejanja človekove pravice in socialno pravičnost. Je poklic, ki je prežet z etičnimi dilemami (saj npr. zahteva presojanje med konflikti interesov in pravic različnih posameznikov, posameznic; skupin ali skupnosti in javnosti) in konflikti vlog (saj socialne delavke delujejo kot zagovornice, podpornice, prevzemajo pa tudi funkcije nadzora, poučevanja, opozarjanja itd.). Etične dileme tako nastajajo na presečiščih vrednot in poklicnih nalog, pri tehtanju med koristmi, pravicami, odgovornostmi, tveganji pri delu z ljudmi in v zvezi z metodami in pristopi, ki jih uporabljajo (glej npr. Banks, 2006, 2016, 2018; Barsky, 2010; Clark 2006; Dolgoff, Loewenberg in Harrington, 2009; McAuliffe, 2014; Strom-Gottfried, 2007). 
V tem (2021) in prejšnjem letu (2020), v času pandemije covida-19, ki je zaznamovala življenje ljudi po vsem svetu, so se tudi nekatere dileme socialnih delavk povečale, se pokazale še v novih razsežnostih ali dobile bolj osrednje mesto v primerjavi s časom pred pandemijo. V prispevku bom predstavila priporočila za etično ravnanje socialnih delavk pa tudi za kolektivne usmeritve poklica, podporo organizacij, kjer socialne delavke delujejo, in za javno prepoznanje stroke socialnega dela. Oblikovanje priporočil temelji na rezultatih raziskave, ki smo jo lansko pomlad opravili skupina raziskovalk in raziskovalcev in ki je želela ugotoviti, katere so osrednje dileme v socialnem delu v času covida-19 (Banks idr., 2020a).

Socialne delavke najpogosteje sodelujejo z osebami, skupinami in skupnostmi, ki se srečujejo z revščino, težavami z različnimi vidiki zdravja, rasizmom in drugimi oblikami zatiranja in neenakosti, stigmo in izključenostjo - in te osebe in skupnosti gotovo občutijo posledice pandemije in ukrepov, povezanih z njo, zelo močno ali še bolj kot tisti, ki sicer ne živijo v stiski. Pritiski in stiske, ki jih povzročajo izgube služb, socialna izolacija, slabo zdravje, žalovanje ipd. ter nedostopnost in zapiranje nekaterih storitev socialnega varstva, radikalno spreminjajo življenja ljudi, zato za socialne delavke pomenijo tudi nove (in pogosto zahtevnejše) okoliščine dela - tako z vidika časa in materialnih virov kot tudi $\mathrm{z}$ vidika dilem ter nasprotujočih si vrednot in interesov. Razkorak med viri (finančnimi, storitvenimi, človeškimi) in potrebami so namreč ukrepi za zajezitev virusa še povečali: zapiranje ustanov, prekinitev in nedostopnost storitev, pomoči in oskrbe so gotovo pripomogli $\mathrm{k}$ povečanju stisk in (intersekcijskih) neenakosti (npr. materialna prikrajšanost vpliva na zmožnosti in priložnosti za varovanje pred okužbo, ki so povezane z nedostopnostjo zaščitnih pripomočkov in testiranja oz. uporabe zdravstvenih storitev, z oblikami dostopnega dela, povečano rabo javnega prostora ipd., vse to pa vpliva tudi na možnosti za šolanje otrok, bivanjske razmere ipd.).

V kontekstih, $v$ katerih se pričakuje, da bodo določene vrednote imele prednost pred drugimi (npr. varnost pred avtonomijo), in $v$ katerih imajo določeni vidiki prednost pred drugimi (npr. zdravstveni pred socialnimi), se lahko tudi socialne delavke znajdejo pred večjimi izzivi glede tega, kako udejanjati zavezanost socialnega dela k človekovim pravicam in družbeni pravičnosti. Ko morajo socialne delavke še pogosteje kot sicer opravljati triažo (odločanje o tem, kdo bolj nujno potrebuje pomoč) ali ko so pozvane k temu, da upoštevajo ukrepe prepovedi stika z ljudmi, ki naj bi jim zagotavljale pomoč (gl. prispevek Mešl in Leskošek v tej številki), je implementacija načel socialnega dela še zahtevnejša.

\section{Etične dileme in socialno delo}

Ker se socialne delavke pogosto srečujejo z etičnimi dilemami, obstaja obsežen opus del, ki se ukvarjajo z razreševanjem etičnih problemov in dilem (več o tem opusu in pristopih k razreševanju etičnih dilem v Sobočan, 2013). Ker je etično odločanje v praksi socialnega dela pogosto povezano z etičnimi dilemami, ki jih je mogoče razumeti kot konkurenčne (saj ne gre za izbire, kajti ena - »pravilna« - samodejno izključi druge izbire), etično odločanje pomeni proces, 
ki vodi k odločitvi, katere »etičnosti« ne gre soditi le glede na pravilnost ali sprejemljivost z vidika etičnih načel, ampak tudi glede na proces razmišljanja in tehtanja. Ta proces pa ni popolnoma »splošen« ali »laičen «, ampak odvisen tudi od specifične poklicne usmerjenosti. Odločanje, ki je etično, v tem članku razumem kot proces odločanja, ki je »zunanje« in »notranje« premišljen (Sobočan, 2013, str. 39):

(a) sistematičen: temeljit, motiviran, odgovoren, strokovno kompetenten in z znanjem podkovan pristop, ki vključuje sposobnost za prepoznavanje, odzivanje in ravnanje z etičnimi dimenzijami prakse in delovnega okolja (med/osebni, inter/kolegialni, strukturni in družbeni vidiki);

(b) samo-refleksiven: vključuje poznavanje sebe (svojih vrednot, preferenc in prepričanj ter v kakšnem odnosu so ti s strokovnimi vrednotami); kot tudi vedenje o tem, kakšne etične perspektive posameznica običajno upošteva (tj. pristope etike skrbi, teleološke, deontološke, pragmatične itd.) in zmožnost prepoznavanja kot tudi evalvacije in ravnanja z lastnimi moralnimi sodbami (glede vedenja ljudi, situacij, »dejstev« ipd.).

Izhajam tudi iz tega, da odločanje ne more biti nikoli deskriptivna ali vrednotno nevtralna praksa, saj je vedno vrednotno usmerjena, zato je v kontekstu poklica socialno delo in vrednot, na katerih temelji, vedno umeščena na določeno točko med skrajnostma etičnega in neetičnega. Ker je socialno delo normativen poklic, ki ga vodijo vrednote in je odločanje lahko le vrednotno zaznamovano početje, $\mathrm{v}$ prispevku tudi metodam, teorijam in zakonom ter njihovim učinkom pripisujem vrednotno zaznamovanost ${ }^{1}$. Pritrditi je mogoče avtorjem Dolgoff, Loewenberg in Harrington (2009, str. 9), ki trdijo, da »socialne delavke niso zgolj tehniki, ki rešujejo mehanske probleme [...]. So najprej in predvsem moralne osebe.«

Literatura o socialnem delu ponuja precej različnih modelov etičnega odločanja, ki lahko pomagajo socialnim delavkam pri iskanju najbolj etičnih rešitev dilem in izboljšajo proces odločanja (npr. Congress, 2000; Robinson in Reeser, 2000; Taylor in White, 2000; Osmo in Landau, 2001; Healy, 2005; Strom-Gottfried, 2007; Barsky, 2010; Dolgoff, Loewenberg in Harrington, 2009). Banks (2009) opozarja, da so modeli etičnega odločanja problematični, ker pravzaprav nakazujejo, da je etične vidike situacij mogoče razlikovati od drugih vidikov prakse, npr. tehničnega, političnega, pravnega, nekateri pa tudi navajajo, da je etično dilemo mogoče razrešiti z uporabo poenostavljenega racionalno-deduktivnega modela odločanja.

Čeprav se v tem prispevku strinjam z Banks (2009), pa je mogoče sprejeti tudi trditev Strom-Gottfried (2008, str. 15), ki trdi, da zavestna uporaba modelov za etično odločanje »o etičnih in strokovnih odločitvah, ki vključujejo niz možnosti, usmeritev in posledic«, povečuje zavedanje o tveganjih, koristih in različnih interesih. Modeli za etično odločanje lahko pomagajo natančneje

1 Lahko bi sicer trdili, da v socialnem delu obstajajo tudi izbire, za katere se zdi, da so zgolj tehnične, nepovezane $z$ vrednotnim opredeljevanjem, vendar $v$ tem prispevku ne bom pojasnjevala ali teoretizirala o razlikah med tehničnimi in vrednotnimi izbirami, saj bomo izhajali iz prepričanja, da je tudi socialno delo predvsem moralni poklic in da so tudi socialne delavke moralne akterke. 
prepoznati problem in podrobneje premisliti o vseh informacijah, ki so na voljo, o različnih interesih in različnih posledicah za različne deležnike. Poleg tega lahko modeli za etično odločanje pripomorejo k bolj sistematičnemu in analitičnemu odločanju, spodbujajo pa tudi k refleksiji o moralnih sodbah in motivacijah. Pomagajo tudi razumeti razliko med tem, kaj je mogoče storiti, in tem, kaj bi bilo treba storiti, ter premisliti o različnih moralnih scenarijih in ozavestiti vrednote, ki so relevantne $v$ določeni situaciji.

$\mathrm{V}$ prispevku ne predlagam specifičnega modela etičnega odločanja za lažje ravnanje z dilemami, ampak želim samo nakazati, da si k bolj etičnim odločitvam lahko pomagamo tudi s smiselnimi procesi oz. koraki pri premisleku o izbirah. Ko se v socialnem delu odločamo glede tega, kako ravnati, je najprej pomembno, da prepoznamo lastnosti etične dileme. Katere vloge, načela, odgovornosti in interesi so si pri dilemi v konfliktu? Potem je smiselno razmisliti, kakšne vse možnosti imamo pri reševanju dilemske situacije: morda se zdi, da imamo na voljo samo nekaj nezaželenih izbir. A refleksija in posvetovanje z drugimi nam lahko pomagata, da se razkrijejo še druge alternative oz. strategije za ravnanje z neželenimi izidi.

Poleg tega si pri deliberaciji o etični dilemi pomagamo tudi z etičnimi usmeritvami in etičnim okvirom poklica: morda bodo le nekatere od možnih izbir tudi etične in samo te so lahko strokovno, etično usmerjene izbire, to pa nam pomaga zožiti nabor ustreznih odločitev. Nato je koristno črpati iz različnih virov (strokovnih, znanstvenih ipd.) in izkušenj (poklicnih, uporabniških ipd.). Breme etičnega odločanja lahko zmanjšamo tako, da se posvetujemo s kolegicami, nadrejenimi, osebami, ki imajo specifična, za situacijo relevantna znanja in izkušnje. Ti pogovori in refleksije lahko ponudijo nove vidike situacije ali nam pomagajo utemeljiti določene vrste ravnanj ali korakov pri razreševanju dileme. Ne nazadnje pa je pomembno tudi, da po že sprejeti odločitvi ali ravnanju evalviramo proces in končne izide.

Premislek o izbirah in odločitvi, osvetljen z vidiki etičnega okvira, osebne refleksije, posvetovanj s kolegicami ali pogovorov z uporabniki in uporabnicami, povečuje etične kompetence socialnih delavk in pripomore k boljšim odločitvam v prihodnosti. Pri takšni evalvaciji se socialna delavka lahko vpraša na primer: ali se je situacija razpletla, kot sem upala, da se bo? Če izid ni bil takšen, kot smo si želeli, kako lahko zdaj situacijo izboljšamo/popravimo? Ali je bilo v procesu kaj, kar sem spregledala ali kar bi si želela narediti drugače? Katera etična načela sem najbolj upoštevala?

\section{Raziskava o etičnih izzivih v socialnem delu v času pandemije}

Skupino raziskovalk in raziskovalcev, ki se sicer ukvarjamo z razreševanjem etičnih dilem in etiko $\mathrm{v}$ praksi socialnega dela, je prav v zvezi z etičnim odločanjem in etičnimi dilemami zanimalo, kakšen vpliv ima čas pandemije na to, kako v socialnem delu doživljamo in razrešujemo etične izzive in dileme. Kot smo ugotavljale Banks in sodelavke (Banks idr., 2020c), pandemija sproža politična, strokovna in tudi osebna vprašanja in ustvarja izzive za področje so- 
cialne politike, za prakso socialnih delavk pa tudi za tiste, ki socialnovarstvene storitve uporabljajo. Ta vprašanja med drugim vključujejo: v kakšni družbeni ureditvi in družbi želimo živeti? Kako naj usklajujemo ravnovesje med prioritetami ekonomske vzdržnosti in zdravjem ljudi? Kje je ravnovesje med osebno svobodo in javnim dobrim? Kako naj presojamo, kdo bo v primeru pomanjkanja dobil dostop do zdravstvene opreme, paketov hrane ali namestitve v varne hiše in zavode? Kako se odločimo, ali je pomembneje nekoga, ki potrebuje pomoč, obiskati in mu pomoč zagotoviti ali pa se je osebnemu stiku bolje izogniti? Vse to so vprašanja, povezana s pravicami, odgovornostjo, pravičnostjo, solidarnostjo, skrbjo in odnosi. Kako se nanje odzivamo z oblikovanjem ukrepov in socialnih politik ter v praksi na področju socialnovarstvenih storitev, je ključno (tudi) za uporabnike in uporabnice socialnega dela pa tudi za same socialne delavke.

Politični, družbeni in strokovni odzivi na navedena in podobna vprašanja so vplivali tudi na prakso socialnega dela v času pandemije in zaznamovali izkušnjo uporabnikov in uporabnic socialnega dela ter doživljanje lastnega poklica pri socialnih delavkah. Ukrepi, ki predpisujejo karanteno, so na primer $\mathrm{v}$ socialno delo vnesli negotovost in tveganja na delovnem mestu, delo od doma, zmanjšanje števila storitev in zapiranje ustanov, premik k telefonskemu in digitalnemu kontaktiranju, krčenje timskega dela, prenehanje usposabljanj na praksi za študentke in študente socialnega dela.

Da bi bolje razumeli obseg in značilnosti vpliva časa pandemije na etično raven prakse socialnega dela, je mednarodna skupina raziskovalk in raziskovalcev v sodelovanju z Mednarodno zvezo socialnih delavk in delavcev (IFSW) med 6. in 18. majem 2020 izpeljala spletno anketo. V njej je sodelovalo 607 oseb iz 52 držav, od tega tudi 14 socialnih delavk iz Slovenije. V času zbiranja podatkov so različne države po svetu doživljale različne stopnje epidemiološke situacije v zvezi s covidom-19. Tudi s tem so bili seveda povezani ukrepi, navodila, pooblastila in omejitve na področju socialnega dela v različnih državah (več o tem v poročilu Dominelli idr., 2020), ki so si glede nekaterih vidikov podobni, glede drugih pa zelo različni.

To seveda pomeni, da odzivi socialnih delavk z vsega sveta temeljijo na razponu različnih situacij. Že spomladi 2020 je glede odzivov socialnega dela na pandemijo nastalo več raziskav in poročil. Raziskava, iz katere izhaja moj članek, pa je želela preučiti etične dimenzije vsakdanje prakse socialnih delavk (Banks idr., 2020a). Podatki za raziskavo so bili zbrani v obliki spletnega vprašalnika, $v$ katerem so udeleženke in udeleženci odgovarjali na dve temeljni vprašanji (več o metodoloških vidikih raziskave v Banks idr., 2020a; Sobočan, 2021):

1. Na kratko opišite nekaj etičnih izzivov, s katerimi ste se srečali ali se srečujete v času izbruha pandemije covida- 19 .

2. Opišite specifično situacijo, ki se vam zdi z etičnega vidika velik izziv.

Prejeli smo 505 odgovorov, še dodatna 102 odgovora pa smo prejeli s pomočjo Japonske zveze socialnih delavk in delavcev ter z 11 intervjuji, ki jih je opravila raziskovalka v Hongkongu. Skoraj 80 \% respondentk je navedlo, da se identificirajo v ženskem spolu, polovica vseh pa je imela več kot 11 let delovnih izkušenj na področju socialnega dela. Sodelovalo je tudi 74 študentk 
in študentov socialnega dela. Respondentke opravljajo različne vloge oz. delujejo na različnih področjih socialnega dela, od državnih ustanov do nevladnih organizacij in zasebnih storitev, na področju individualnega in družinskega svetovanja, v skupnostnih programih, v zdravstvenih in skrbstvenih ustanovah, šolah ipd. (dodatna analiza glede na področje dela ni bila opravljena).

Podatke smo analizirali člani in članice raziskovalne skupine, v prvi fazi vsak določen nabor odgovorov, ki smo jih kodirali, v naslednji fazi pa smo vsi pregledali vse preliminarne analize in skupaj oblikovali končne teme, ki izhajajo iz podatkov. Vzorec pridobljenih odgovorov seveda ne omogoča posploševanja, kljub temu pa je analiza pokazala, da lahko iz pridobljenega gradiva natančneje ugotavljamo, kateri etični izzivi v socialnem delu v številnih delih sveta v času pandemije zbujajo največ pozornosti.

Namen raziskave je bil identificirati in razumeti, kateri so specifični etični izzivi, ki so se pojavili v okoliščinah pandemije, in kako se socialne delavke nanje odzivajo ter kakšen moralni vpliv imajo nanje. Eden od ciljev raziskovalk in raziskovalcev je bil tudi oblikovati priporočila za etično odločanje socialnih delavk v praksi. Priporočila za ravnanje z dilemami, ki izhajajo iz predstavljene raziskave, so bila na začetku novembra 2020 objavljena na spletni strani IFSW (Banks idr., 2020b) in jih natančneje predstavljam v tem prispevku.

\section{Priporočila za etično prakso v socialnem delu v času pandemije}

Analiza podatkov, pridobljenih z raziskavo, je omogočila identifikacijo šestih ključnih tematskih oz. dilemskih polj, ki so povezana z etičnimi dimenzijami dilem in prakse socialnih delavk (več o rezultatih raziskave v Banks idr., 2020a; 2020b; 2020c). Analiza odgovorov socialnih delavk iz Slovenije je natančno predstavljena v prispevku Sobočan (2021). Na podlagi prepoznanih tematskih področij v tem članku predstavljam tudi priporočila za prakso socialnega dela (gl. Banks idr., 2020b).

A. Vzpostavljanje in ohranjanje zaupnih, odkritih in sočutnih odnosov po telefonu ali prek spletne komunikacije s potrebnim upoštevanjem zasebnosti in zaupnosti ali osebno v zaščitni opremi.

Čeprav se v številnih držav uporaba informacijskih in komunikacijskih tehnologij (IKT) v socialnem delu povečuje, smo bili v času pandemije pogosto priče tudi popolni nadomestitvi medosebnega stika s stiki prek telefona ali spletne komunikacije. Posebej velik izziv v takšnih okoliščinah pomeni sodelovanje z ljudmi, ki nimajo dostopa do IKT ali nimajo spretnosti za njihovo uporabo (in lahko zato popolnoma izgubijo dostop do socialnovarstvenih storitev), ter možnost za ustrezno strokovno oceno situacij, ki jih spremljamo le na daljavo. Drugi etični izzivi vključujejo tudi ogroženo pravico do zasebnosti in zaupnosti, nezmožnost ustrezne strokovne ocene potreb, okoliščin in dejavnikov tveganja pri ljudeh, s katerimi sodelujemo, težave pri vzpostavljanju sočutnih in zaupnih odnosov, nezmožnost zagotavljanja meje med osebnim in poklicnim (npr. pri delu od doma) ipd. Zato si je v socialnem delu pomembno prizadevati za: 
1. Možnost razvijanja spretnosti pri uporabi ustreznih IKT, poznati stopnjo varnosti pri uporabi teh sistemov v službi in imeti možnosti podpore in dodatnih izobraževanj, kadar jih potrebujemo.

2. Pomoč uporabnicam, uporabnikom pri rabi IKT na varen in zaseben način ter jim predstaviti prednosti in tudi omejitve (nevarnosti) rabe različnih oblik komunikacije.

3. Ugotavljanje - skupaj z uporabnicami, uporabniki - katere vrste komunikacije so zanje možne in sprejemljive, da tako podpremo njihovo avtonomijo in povečujemo njihovo zaupanje.

4. Pozornost na okvire profesionalnega dela, še posebej takrat, ko delamo od doma ali moramo za to, da bi dosegli ljudi, uporabljati manj varne oblike komunikacije.

5. Pogovor z uporabniki, uporabnicami o tem, kako je mogoče trenutno izvajati socialno delo in kako lahko v novih okoliščinah skrbimo za zaupnost.

6. Razmislek o tem, kako poskrbeti za zaščito in kako lahko kljub omejitvam in zdravstvenim tveganjem ohranjamo osebne stike in skrbimo za izražanje sočutja.

B. Določanje prednosti potreb uporabnikov in uporabnic socialnega dela (ki so zaradi pandemije večje ali drugačne kot sicer) v okoliščinah zmanjšanih ali ukinjenih sredstev za pomoč in nezmožnosti ustrezne strokovne presoje.

Zagotavljanje pravične porazdelitve finančnih sredstev in časa, ki ga socialne delavke namenjajo uporabnicam in uporabnikom, je bilo od nekdaj velik izziv, v času pandemije pa je odločanje še zahtevnejše, saj so potrebe povečane, nekatere storitve prekinjene ali omejene, socialne delavke pa imajo navodila, da se morajo ukvarjati samo z nujnimi primeri in situacijami. Največji etični izzivi so tako povezani z razdeljevanjem materialne pomoči, s konflikti med interesi ali varnostjo socialnih delavk ter uporabnikov, uporabnic in različnih ranljivih skupin; s strahom pred neustrezno oceno in odzivom na tvegane situacije (npr. pri starih ljudeh, otrocih, v primerih družinskega nasilja); z negotovostjo glede pripravljenosti strokovnega kadra, prostovoljcev in drugih pri zagotavljanju pomoči; s strahom pred tem, da bomo pripomogli k povečevanju družbenih neenakosti - zaradi pomanjkanja materialnih sredstev ali pomoči. Zato je pomembno, da v socialnem delu:

1. Se skupaj s kolegicami, tudi iz drugih poklicev (npr. zdravstvenega), vključujemo v oblikovanje skupnih vodil in praks za pravično in spoštljivo zagotavljanje pomoči v kriznih situacijah.

2. Imamo supervizijo in možnost intervizije ali posvetovanja z drugimi, da bi čim bolje lahko prepoznavali najpomembnejše prioritete, prepoznali različne vire in presojali, kateri načini dela so najpravičnejši in najspoštljivejši.

3. Smo pozorni na lastno ranljivost, duševno zdravje pa tudi varnost in si poiščemo svetovanje ali pomoč v zvezi s tem, kako etično in učinkovito skrbeti za ravnovesje med svojimi potrebami in potrebami drugih.

4. Vzdržujemo redne stike z uporabnicami, uporabniki - kakorkoli je to že mogoče (če osebni stik ni možen ali je preveč tvegan, vzdržujemo stike na druge načine, npr. z uporabo IKT). 
5. Proaktivno nenehno poročamo o ugotovitvah iz prakse, npr. o nepravičnih socialnih politikah, pomanjkanju materialnih sredstev, pomanjkanju kadra, nedostopnosti storitev.

C. Iskanje ravnovesja med pravicami, potrebami in tveganji za uporabnike in uporabnice ter osebnimi tveganji socialnih delavk, ki želijo svoje delo in zagotavljanje pomoči opraviti čim bolje.

Ocena tveganja je ena od nalog v socialnem delu, ravnanje s tveganji pa del vloge socialnega dela, vendar so $\mathrm{v}$ času pandemije številne naloge $\mathrm{v}$ socialnem delu (terensko delo, osebno svetovanje, delo v zavodih in dnevnih centrih ipd.) postale tvegane $\mathrm{z}$ vidika prenosa virusa, pogosto pa tudi nedovoljene ali prekinjene. $\mathrm{V}$ raziskavi so socialne delavke kot pogosto etično dilemo navedle odločanje o tem, kdaj kljub prepovedi vlade ali organizacij, v katerih delajo, imeti osebni stik. Pri tem so se spraševale, kako veliko tveganje tudi same pomenijo za ljudi, s katerimi sodelujejo, in kako usklajevati različne konfliktne potrebe, interese in pravice. Nenehno so se tudi spraševale, ali in koliko lahko same posegajo v pravice in svoboščine ljudi in se glede teh odločajo glede na epidemiološka tveganja in čemu dati prednost (npr. fizičnemu zdravju s preprečevanjem nevarnosti okužbe ali duševnemu zdravju z obiskovanjem osamljenih). Zato je pomembno, da si v socialnem delu znamo izbojevati:

1. Čas za premišljeno oceno potreb, pravic in interesov ljudi, ki potrebujejo in iščejo pomoč, da bi tako zagotovili, da so ocene uravnotežene in da so v ospredju resnično največje koristi uporabnikov, uporabnic.

2. Ustrezno osebno zaščitno opremo, da smo lahko v osebnem stiku z ljudmi, tudi kadar epidemiološke razmere tega ne dopuščajo.

3. Možnosti za prilagajanje storitev in okvirov dela tako, da lahko zagotavljamo pomoč in storitve, ki jih ljudje potrebujejo, na način, ki je zanje najboljši.

4. Ravnanje, ki je spoštljivo do uporabnikov, uporabnic in je v skladu s poklicno odgovornostjo in ne ogroža same socialne delavke.

5. Supervizijo, ki omogoča kritično refleksijo in analizo lastne prakse, premišljevanje o lastnih procesih odločanja in oceno rezultatov dela.

Č. Odločanje o tem, ali bi upoštevale državne ukrepe ali navodila in procedure $v$ organizaciji, kjer so zaposlene, ali pa strokovno diskrecijo $v$ okoliščinah, $v$ katerih se ukrepi in navodila zdijo neprimerni, nerazumljivi ali pomanjkljivi. Po poročanju socialnih delavk v naši raziskavi so bile številne organizacije, v katerih delujejo, nepripravljene na novo situacijo, posledica tega pa so bila pogosto ambivalentna, neustrezna ali nenehno spreminjajoča se navodila in pričakovanja. Tako so se socialne delavke znašle v situaciji, $\mathrm{v}$ kateri naj bi s »socialno distanco« izvajale socialno delo, poklic, ki temelji na vzpostavljanju odnosov. Številne so se - v izolaciji svojega doma, ne skupaj s kolegicami - odločale, ali naj upoštevajo navodila, ki so bila pogosto kontradiktorna, včasih tudi napačna, in razmišljale, kako naj nasprotujejo navodilom in uredbam, jih spreminjajo ali ignorirajo. Zato je pomembno, da socialne delavke: 
1. Premišljujemo o pravilih in uredbah, ki naj bi jih upoštevale, in ugotavljamo, kakšne so njihove posledice za pravice, potrebe, dostojanstvo in varnost ljudi, s katerimi sodelujemo.

2. Konstruktivno pretresamo pravila ali zahteve, za katere ocenjujemo, da so v nasprotju z etičnimi načeli socialnega dela, še posebej, kadar ogrožajo človekove pravice in dostojanstvo.

3. V sodelovanju s kolegicami razvijamo in predlagamo drugačne, stroki bližje pristope.

4. Smo pripravljene uporabiti strokovno diskrecijo pri odzivanju na etično zahtevne situacije (in če je le mogoče, s posvetovanjem z nadrejenimi in kolegicami, ki jim znamo utemeljiti, zakaj želimo ravnati na določen način).

5. Prevzemamo odgovornost za etične odločitve. To je še posebej pomembno takrat, ko z odločitvami nasprotujemo pravnim zahtevam ali protokolom ravnanja.

D. Prepoznavanje in obvladovanje lastnih čustev, izčrpanosti in skrbi zase $v$ okoliščinah, ki so stresne in niso varne

Kot je mogoče pričakovati v kriznih okoliščinah, so socialne delavke poročale o močnih čustvih, od strahu, anksioznosti, jeze, sramu, razočaranja in občutkov krivde do žalosti in žalovanja. Različna in že tako intenzivna čustvena stanja so pogosto poslabšale tudi osebne okoliščine in zmanjšana institucionalna in kolegialna podpora (npr. v povezavi z delom od doma) ter kritike in neprepoznavanje njihovega dela. Največji izzivi, o katerih so poročale socialne delavke v zvezi s tem, so bili: predvsem pritiski na socialne delavke (medtem ko so hkrati doživljale negativna ali konfliktna čustva); iskanje načinov, kako ohraniti profesionalno integriteto in s stresnimi situacijami ravnati profesionalno; zmožnost prepoznavanja, kdaj lahko osebne reakcije zameglijo strokovno presojo in zmanjšajo profesionalnost, kdaj pa morda lahko pripomorejo $\mathrm{k}$ motivaciji in kritični refleksiji.

Zato je zelo pomembno, da socialne delavke:

1. Spoštujemo in izražamo lastno strokovno, etično integriteto, vzdržujemo ustrezne profesionalne meje in skrbimo za ravnovesje $\mathrm{v}$ poklicni vlogi - $\mathrm{s}$ pozornostjo na lastno osebno in čustveno vpletenost $v$ strokovno delo.

2. Prepoznavamo potrebe po zmanjševanju stresa pri zmožnosti za etično in učinkovito opravljanje strokovnega dela.

3. Razlikujemo racionalne premisleke in čustvene reakcije pri ocenjevanju situacij in odločanju glede ravnanja.

4. Smo pozorne do sodelavk, ki potrebujejo čustveno podporo ali pomoč pri spoprijemanju z etičnimi, praktičnimi in osebnimi izzivi v strokovnem delu.

5. Zahtevamo, spodbujamo in udejanjamo tiste prakse $\mathrm{v}$ organizacijah, kjer delamo, ki podpirajo socialne delavke pri tem, da lahko delujejo z etično integriteto in strokovno, pri tem pa ne škodujejo svojemu duševnemu ali telesnemu zdravju. 
E. Uporaba izkušenj, pridobljenih v času pandemije, za razmislek o socialnem delu v prihodnosti.

Okoliščine pandemije so pokazale tudi nujnost premisleka o vlogah, nalogah in praksi socialnega dela pa tudi o tem, da je treba biti na prihodnje podobne situacije bolje pripravljen. Pokazalo se je namreč: da krizne situacije vplivajo na to, koliko časa imamo za etično refleksijo in timsko delo; da smo časovno in kadrovsko omejeni glede presoje, kaj v kriznih okoliščinah deluje in kakšno ravnanje je etično sprejemljivo; da dajanje prednosti zdravstvenim potrebam pomeni, da sta lahko spregledana ključna vloga socialnih delavk in vpogled $\mathrm{v}$ resnične izkušnje ljudi v vsakdanjem življenju; da obstaja nevarnost, da bodo »triažno" delo v socialnem delu ter digitalna komunikacija in druge nove oblike dela postali običajni v običajnih razmerah, to pa bi lahko vplivalo npr. na nepravičnost in nespoštovanje dostojanstva ljudi. Zato je pomembno:

1. Socialne delavke se moramo znova poglobiti v etična načela (vključena $v$ mednarodne dokumente socialnega dela in nacionalne etične kodekse), saj je njihova uporaba v kriznih časih lahko drugačna.

2. Medsebojno se moramo posvetovati glede etičnih dilem in izzivov (s sodelavkami v okviru poklicnih združenj ipd.), da dobimo nove poglede na to, kako se odločati v vsakdanjih situacijah.

3. Bojevati se moramo za to, da imamo čas za individualno refleksijo in refleksijo v timu, da se lahko učimo iz izkušenj in skupaj načrtujemo, kako naša delovna okolja po potrebi preoblikovati, da bi bila bolj etična.

4. Vključevati se moramo v procese etičnega odločanja, da bi ugotavljali, katera ravnanja so pravilna (čeprav zahtevna), katere vrednote in načela socialnega dela so relevantni za posamezne situacije in katere vrednote imajo morda v spremenjenih okoliščinah večji pomen.

5. Zavzemati se moramo za izboljšanje pravic in kakovosti življenja ljudi; za izboljšanje dostopnosti storitev in povečevanje človeških in materialnih virov v socialnem delu - v organizacijah, kjer delamo, pri političnih odločevalcih in vseh, ki na to lahko vplivajo.

6. Zagovarjati moramo temeljno vlogo, ki jo ima socialno delo pri zagotavljanju pomoči, ki je tako vitalna kot zdravstvena oskrba za to, da lahko posamezniki, posameznice, družine in skupnosti preživijo pandemijo.

\section{Sklepi}

$\mathrm{V}$ raziskavi, na podlagi katere so oblikovana tudi navedena priporočila za ravnanje (Banks idr., 2020a), smo prepoznali tudi pogosto izraženo željo po vplivnejšem in bolj avtonomnem socialnem delu, po več sodelovanja med različnimi poklici in ekspertizami ter bolj integriranem zdravstvenem, socialnovarstvenem in ekonomskem sistemu pomoči. V odgovorih iz številnih držav je bilo razbrati tudi nujnost večjega strokovnega in družbenega prepoznanja vloge socialnega dela ter aktivne vloge socialnega dela pri načrtovanju ukrepov in odločitev v prihodnjih kriznih situacijah - tako bomo, kot so poudarile socialne delavke, bolje pripravljeni na odzivanje na stiske ljudi. 
Morda najpomembnejše sporočilo raziskave v zvezi s projekcijami o prihodnosti socialnega dela pa je, da so socialne delavke izražale tudi strah pred tem, da bodo prakse, ki so se uveljavile med pandemijo, še posebej v njenem prvem obdobju (malo ali nič osebnega stika, urejanje večine zadev po telefonu, avtomatizacija nekaterih postopkov), postale stalna praksa.

Številne socialne delavke so poudarile, da je delo v času pandemije razkrilo in povečalo obstoječe pomanjkljivosti $\mathrm{v}$ organizaciji in pri izvajanju socialnega dela. Zato se je pomembno znova vprašati o nalogah, vlogah in vrednotah socialnega dela ter prepoznati priložnosti in znanja, izhajajoča iz izkušnje pandemije, ki naj nas spodbudijo, da v socialnem delu ostanemo, kot trdita O'Leary in Tsui (2020, str. 2017), usmerjeni k udejanjanju človekovih pravic. Nova podpora vrednotam poklica lahko temelji tudi na novih znanjih in kreativnosti socialnih delavk po vsem svetu, pri njihovem iskanju in vztrajnem uresničevanju družbene pravičnosti ter obnavljanju socialnega dela kot skupnostne prakse, katere osrednja cilja sta družbena pravičnost in vključenost (glej tudi: IFSW, 2020; Miller in Lee, 2020; Truell, 2020).

Ob povečevanju družbenih neenakosti, nepravični porazdelitvi virov, nedostopnosti pomoči in oskrbe, povečevanju stisk in pogosto veliki nemoči socialnega dela pri odzivanju na vse to se upravičeno lahko vprašamo, ali lahko etika socialnega dela sploh vzdrži? V članku sem navedla nekaj idej o tem, kako skrbeti za etične pristope tudi v času novih oz. neznanih izzivov. Da pa bi se v obdobjih kriz (in tudi sicer) lahko odzivali na navedene izzive strokovno, etično, je moralni značaj treba nenehno razvijati in krepiti: individualno in predvsem kolektivno. Tudi zelo moralne osebe izgorijo v okoljih brez kulture etike, hkrati pa osebe, ki niso zelo moralne, lahko postanejo bolj etične v okoljih, ki spodbujajo etično ravnanje in vedenje. Pojavlja se jasna potreba po tem, da bi se zmanjšal strah pred kaznovanjem in šikaniranjem socialnih delavk v okoljih, kjer so zaposlene (Webb, 2006; Kemshall, 2010; Sobočan, 2013) in da bi se vodenje in supervizija $v$ delovnih kontekstih razvila tako, da bi podpirala dobro prakso (v praktičnem in moralnem pomenu) (Stanford, 2011, str. 1527).

Kolektivno razvijanje etične usmerjenosti stroke pomeni razvijanje kolektivne poklicne identitete, ki naj postane temelj in okvir za vso prakso socialnih delavk in tudi določa organizacijsko kulturo v socialnovarstvenih okoljih. To pomeni:

1.) razumevanje tako ciljev poklica socialno delo kot tudi specifičnih vrednot, na katerih temelji; pa tudi razvijanje znanja o medsebojni povezanosti teh vrednot in njihovi konfliktni naravi ter posledicah, ki izhajajo iz teh vrednot (v realnem življenju),

2.) krepitev usmerjenosti k vrednotam socialnega dela in razumevanje, kako se te povezujejo s posameznikovimi osebnimi vrednotami, pa tudi razvijanje sposobnosti za refleksijo o njih in za razpravljanje o vrednotah, pojasnjevanje lastnih ravnanj skozi prizmo vrednot,

3.) krepitev spretnosti za zagovarjanje poklicnih vrednot in za njihovo uresničevanje.

Kolektivno sprejemanje poklicnih vrednot pomeni, da tudi organizacije, kjer so socialne delavke zaposlene upoštevajo in zagovarjajo vrednote in cilje 
socialnega dela ter spodbujajo socialne delavke pri etičnih pristopih v praksi (tudi kadar to pomeni konflikte z zakonodajo ali drugimi avtoritetami), ne pa da jih ovirajo. Le takšna, kolektivna etična kultura lahko zagotavlja, da se bo okrepila tudi poklicna avtonomija, in pripomore k avtoriteti etičnih odločitev socialnih delavk v odnosu do drugih. Hkrati bodo socialne delavke pri opiranju na poklicno identiteto lahko uspešneje uresničevale svoje etične dolžnosti in tudi prevzemale odgovornost za etično prakso in etično odločanje - tako v času velikih kriz kot tudi sicer.

\section{Zahvale}

Zahvaljujem se članicam in članom raziskovalne skupine, s katerimi smo zasnovali, oblikovali in izvedli raziskavo ter interpretirali pridobljene podatke in pripravili poročila in priporočila za ravnanje, iz katerih izhaja tudi tale članek: Sarah Banks (Durham University), Tian Cai (Durham University), Ed de Jonge (Utrecht University of Applied Sciences), Jane Shears, (BASW in IFSW), Michelle Shum (Hong Kong Baptist University), Kim Strom (UNC Chapell Hill), Rory Truell (IFSW), Maria Jesus Uriz (Public University of Navarre) in Merlinda Weinberg (Dalhousie University).

\section{Viri}

Banks, S. (2006). Ethics and values in social work. Basingstoke: Palgrave Macmillan.

Banks, S. (2009). From professional ethics to ethics in professional life: implications for learning, teaching and study. Ethics and Social Welfare, 3(1), 55-63.

Banks, S. (2016). Everyday ethics in professional life: social work as ethics work. Ethics and Social Welfare, 10(1), 35-52.

Banks, S. (2018). Practising professional ethical wisdom: the role of "ethics work" in the social welfare field. V D. Carr (ur.), Cultivating moral character and virtue in professional practices (str. 55-69). Abingdon: Routledge.

Banks, S., Cai, T., de Jonge, E., Shears, J., Shum, M., Sobočan, A. M., Strom, K., Truell, R., Úriz, M. J., \& Weinberg, M. (2020a). Ethical challenges for social workers during Covid-19: a global perspective. Rheinfelden, Switzerland: International Federation of Social Workers. Pridobljeno 1. 7. $2021 \mathrm{~s}$ https://www.ifsw.org/wp-content/uploads/2020/07/2020-06-30-Ethical-Challenges-Covid19-FINAL.pdf

Banks, S., Cai, T., de Jonge, E., Shears, J., Shum, M., Sobočan, A. M., Strom, K., Truell, R., Úriz, M. J., \& Weinberg, M. (2020b). Practising during pandemic conditions: ethical guidance for social workers. Rheinfelden, Switzerland: International Federation of Social Workers. Pridobljeno 1. 7. $2021 \mathrm{~s}$ https://www.ifsw.org/practising-during-pandemic-conditions-ethical-guidance-for-social-workers/

Banks, S., Cai, T., de Jonge, E., Shears, J., Shum, M., Sobočan, A. M., Strom, K., Truell, R., Úriz, M. J., \& Weinberg, M. (2020c). Practicing ethically during COVID-19: social work challenges and responses. International Social Work, 63(5), 569-583.

Barsky, A. E. (2010). Ethics and values in social work: an integrated approach for a comprehensive curriculum. New York: Oxford University Press.

Clark, C. L. (2006). Moral character in social work. British Journal of Social Work, 36, 75-89.

Congress, E. (2000). What social workers should know about ethics: understanding and resolving practice dilemmas. Advances in Social Work, 1(1), 1-25. 
Dolgoff, R., Loewenberg, F., \& Harrington, D. (2009). Ethical decisions for social work practice (osma izdaja). Belmont, CA: Thomson, Brooks Cole.

Dominelli, L., Harrikari, T., Mooney, J., Leskošek, V., Tsunoda, K. (ur.) (2020). Covid-19 and social work: a collection of country reports. Pridobljeno 10. 10. 2020 s https://www.iasswaiets.org/wp-content/uploads/2020/07/IASSW-COVID-19-and-Social-Work-Country-Reports-Final-1.pdf

Healy, K. (2005). Social work theories in context: creating frameworks for practice. Houndmills, Basingstoke, Hampshire, New York: Palgrave Macmillan.

IFSW (2020). International Federation of Social Workers. The social work response to covid-19 - six months on: championing changes in services and preparing for long-term consequences, Rheinfelden, Switzerland: International Federation of Social Workers. Pridobljeno 10. 7. 2021 s https://www.ifsw.org/wp-content/uploads/2020/07/2020-07-01SW-Response-to-COVID-19-Six-Months-On.pdf

Kemshall, H. (2010). Risk rationalities in contemporary social work policy and practice. British Journal of Social work, 40, 1247-1262.

McAliffe, D. (2014). Interprofessional ethics: collaboration in the social, health and human services. Melbourne: Cambridge University Press.

Miller, V., \& Lee, H. (2020). Social work values in action during COVID-19. Journal of Gerontological Social Work 63(6-7). Pridobljeno 3. 7. $2021 \mathrm{~s} \mathrm{https://www.tandfonline.com/doi/}$ abs/10.1080/01634372.2020.17697

O'Leary, P., \& Tsui, M.-S. (2020). Social work's role during and after the pandemic: keeping vigilant and hopeful on human rights. International Social Work, 63(4), 417-418.

Osmo, R., \& Landau, R. (2001). The need for explicit argumentation in ethical-decision making in social work. Social Work Education, 20, 483-492.

Robinson, W., \& Reeser, L. (2000), Ethical decision making in social work. Boston: Allyn and Bacon.

Sobočan, A. M. (2013). Etika v socialnem delu (doktorska disertacija). Ljubljana: Fakulteta za socialno delo, Univerza v Ljubljani.

Sobočan, A. M. (2021). Čas pandemije in izzivi socialnega dela v Sloveniji in po svetu. Družboslovne razprave, 37(96/97), 79-97.

Stanford, S. N. (2011). Constructing moral responses to risk: a framework to hopeful social work practice. British Journal of Social Work, 41, 1514-1531.

Strom-Gottfried, K. (2007). Straight talk about professional ethics. Illinois: Lyceum Books.

Strom-Gottfried, K. (2008). The ethics of practice with minors: high stakes, hard choices. Chicago: Lyceum Books.

Taylor, C., \& White, S. (2006). Knowledge and reasoning in social work, educating for humane judgement. British Journal of Social Work, 36, 937-954.

Truell, R. (2020). Covid-19: the struggle, success and expansion of social work. Rheinfelden, Switzerland: International Federation of Social Workers. Pridobljeno 10. 7. $2021 \mathrm{~s} \mathrm{www.}$ ifsw.org/covid-19-the-struggle-success-and-expansion-of-social-work

Webb, S. A. (2006). Social work in a risk society: social and political perspectives. Basingstoke: Palgrave MacMillan. 
